\title{
Assessing Knowledge and Religiosity on Consumer Behavior towards Halal Food and Cosmetic Products
}

\author{
Ahlam Nuwairah Ahmad, Azmawani Abd Rahman, and Suhaimi Ab Rahman
}

\begin{abstract}
This paper investigates the relationship between knowledge and religiosity on attitude towards Halal food and cosmetic products. It also looks at existence of significant difference between consumers' attitude towards Halal cosmetic and Halal food products were investigated. Based on the sample of Malaysian Muslim consumers, results show that religiosity is more influential towards behavior compared to knowledge pertaining to halal matters and there is a significant difference on respondent's behavior between halal food products and halal cosmetic products. The results of the study give implication to firms competing in cosmetic industry. Religiosity is one of the main factors that should be taken into account in promoting their cosmetic products.
\end{abstract}

Index Terms-Attitude, cosmetic product, food products, halal, knowledge, Malaysia, religiosity.

\section{INTRODUCTION}

Cosmetics nowadays can be classified as a 'must-have' item not only for women but also for a minority of man with a metrosexual personality. The increasing number of Muslims around the world and the raise of awareness among their recent generations are two crucial reasons behind the new trend in the change of behavior among Muslim consumers [1] Since Muslims are aware about the prohibition from using alcohol, pork and any other related items, this may led to rapidly rising demand for halal cosmetics and personal care products. In Malaysia, cosmetics and toiletries market recorded sales of approximately RM3billion in 2003, with the growth rate of $13 \%$ annually [2]. The same source also claimed that there are over 60,000 types of cosmetics available in the local market. Among the cosmetic company exist in Malaysia are Avon, Cosway and Maybelline; for mass market, Estee Lauder, Clinique and Shiseido; for prestige brands, and also Body Shop, Sasa and Roche; for franchise chains.

Cosmetics and toiletries industry also receive an impact on this global halal awareness and as a result, the demand for halal cosmetic is rising worldwide [3]. This phenomenon has urge marketers to seek halal certificate in order to capture this halal emerging market. This Halal cosmetics and toiletries market is expected to increase globally by $8.5 \%$ by 2014 and it represents one of the few markets that portray a stable growth [4]. According to [5], [6] claims that those who use halal are always loyal to halal brands so there is no serious

Manuscript received September 16, 2013; revised November 25, 2013.

A. N. Ahmad and S. Ab Rahman are with the Faculty of Economics and Management, Universiti Putra Malaysia, Selangor, Malaysia (e-mail: nuwairah_nunu@yahoo.com, suhaimi@econ.edu.my).

A. Abd Rahman is with the Halal Product Research Institute, Universiti Putra Malaysia, Serdang, Selangor, Malaysia (e-mail: azar@upm.edu.my). impact of the downturn and as in [7] stated that even non-Muslim Europeans are purchasing halal products due to the perception that they are safe and wholesome.

According to [8], chemicals \& chemical products is one of the leading industries in Malaysia, maintaining its second position as the largest contributor which contributes 10 percent to Malaysia's total exports of manufactured goods. In 2011, this product has recorded an increase 16 percent reaching RM 47.2 billion compared to RM 40.7 billion in the previous year. Essential Oils and Perfume Materials, Cosmetics, Toilet and Cleansing Preparations significantly contributed to the increased by 11.9 per cent, to RM3.5 billion. The increase was contributed by a higher (5.2 per cent) export of soap, cleansing and polishing preparations valued at RM2.5 billion.

\section{Problem Statement And ObJective of THE Study}

Halal food trade has picked up rapidly while more and more countries have been adopting Islamic Finance in their banking system. Halal cosmetics and personal cares are next in line in the Halal Business. In fact increasing number of companies throughout the world are now producing halal cosmetics and personal cares in order to tap this burgeoning market.

Most of cosmetic and other personal care products are made by non-Muslim manufacturers and came from non-Muslim country which can be disputed about the halalness of its ingredients. Many cosmetics contain alcohols as humectants that help deliver ingredients into skin, emollients, or cleansing agents. Equally, some of the fatty acids and gelatine used in products such as moisturisers, shampoos, face masks and lipsticks are derived from pigs [9]. In addition, the cosmetics and pharmaceutical sector was subject to greater scrutiny by Muslim scholars on the suspicion that many international brands are using enzymes extracted from pork meat or alcohol as a preservative, generating great deal of cynicism towards these brands in Muslim customers [10]. This can be an example of reason why Muslim consumers are now seeking halal cosmetic products.

Existing literatures provide a number of factors that influence consumers to choose halal products. The literatures, however, only focused on the halal food products and only limited number of literature were studied about halal cosmetic products. Nowadays, because of the demand for halal cosmetics products worldwide is rising, this study has attempted to discuss the two factors that may influence consumer behavior towards halal cosmetic products. The said two factors are consumer knowledge pertaining to halal 
matters and and consumer's level of religiosity. In addition, this study also aims to identify if there is a differences between behavior towards halal food and halal cosmetic products. As such, the objectives of the study are; to identify the relationship between consumer Halal knowledge and consumer behavior towards Halal cosmetic products; to identify the relationship between religiosity and consumer behavior towards Halal cosmetic products; and to identify if there is a significant different on purchase behavior between Halal food products and Halal cosmetic products. The framework of the study is depicted as below:

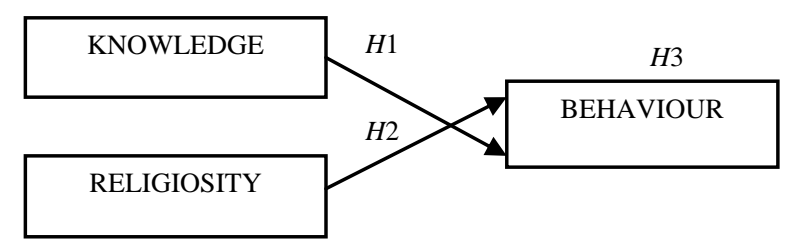

Fig. 1. Framework.

\section{LITERATURE REVIEW AND HYPOTHESIS FORMATION}

Existing study about knowledge has discussed on knowledge about Halal food among food manufacturers in Malaysia aimed at measuring the knowledge level on food hygiene and the concept of halal food amongst the food industries entrepreneurs [11]. The results found that majority of the marketers have a sufficient knowledge about Halal food and they are aware that food which contained with unslaughtered or diseased animals is forbidden according to Muslim rites. Even though there already have some studies conducted about knowledge lack of understanding were sought focusing on consumer's knowledge on Halal and its impact on perception towards halal cosmetic products.

Past research regarding knowledge has proven that knowledge has a positive influence on attitude towards organic food. According to [12], several researchers have reported that greater awareness and additional knowledge concerning organic food has a positive influence on attitudes towards organic food and levels of consumption [13]-[17]. Hence, it is hypothesized that knowledge has a positive influence on attitude towards Halal cosmetic products.

H1: Knowledge will be positively correlated with behavior towards Halal cosmetic products

Religion can be considered as very important indicator in any decision making processes where it is the foundation that leads a person to behave lawfully and ethically. According to [18], religiosity is the extent to which an individual is committed to his religion, where it is then reflected in his/her attitudes and behavior. In simple words, religiosity is the degree of being religious [19], [20]. Reference [21] claims that religious is one of the subculture components other than nationality, racial and geographical region, which have the most influential determinants of human behavior. Past consumer behavior researchers have found that there is a significant relationship between a consumer's religious affiliation and a number of consumption related variables. Reference [22] concluded that few other variables exhibited the range and depth of explanatory power offered by religious affiliation. Although there has been a few research on the relationship between religiosity and consumer behavior, understanding on the impact of religiosity on the attitudes towards halal cosmetic products are still scarce.

According to [23], [24], religion can influence consumer attitude and behavior as well as food purchasing decision and eating habits [25]. Based on this past research statement, there has been proven that religiosity can influence consumer behavior. However, this past research has focused on food purchasing decision and eating habit only. As such, it is hypothesized that there is a positive relationships between religiosity and consumer behavior on Halal cosmetic products.

$\mathrm{H} 2$ : Religiosity will be positively correlated with behavior towards Halal cosmetic products

\section{MEthodology}

This study had used survey method in order to collect data and the data were obtained via self-administered questionnaire. Most of the questions are open-ended questions. As the main focus of this study is to examine the relationship between consumer's Halal knowledge and religiosity towards their behavior on Halal cosmetic products among consumers in Malaysia, a short questionnaire was formed containing specific questions related to consumer behavior towards both halal food and cosmetic products. Also, questions on knowledge are aimed to see whether respondents have enough information pertaining to halal matters. In addition, the questions also ask about consumer's commitment towards their religiosity (Islam) since this study has focused its target respondent to the Muslim consumers.

The questionnaire is divided into four sections. The first section is about the respondent's knowledge regarding Halal where the 5-likert scale questions were adopted from [26]. The second section is regarding the religiosity of the respondent. This section used 5-likert scale questions to ask respondent about their commitment to the religion. The questionnaires in this section were adopted from [27]. The third section is about respondent's behavior towards halal cosmetic and halal food products where the questions is also use the 5-point likert scale. The questions in this section were adopted from [27]-[29]. The questionnaire was distributed using convenience sampling method where this method allow researcher to obtain those respondents that are most conveniently available. At the end of the data collection period, 110 responses were usable for further analysis. Data were analyzed using the latest version of SPSS software.

\section{DATA ANALYSIS AND FINDINGS}

Table I shows the descriptive statistics of respondents while figure 2 shows results regarding respondent knowledge on halal logo. Respondents were asked to indicate in the questionnaire whether the given halal logo is approved by Department of Islamic Development Malaysia (JAKIM). Among the six logos, only two logos approved by JAKIM which are $\log 05$ and 6 . Results indicate, for $\log 01$, only 
$30.9 \%$ of the respondents answered correctly while $21.8 \%$ of the respondents answered incorrectly and majority of the respondents $(47.3 \%)$ were not sure about the logo whether it approve or not. For logo 2, majority of the respondents answered incorrectly $(76.4 \%)$ while only $10.9 \%$ of respondents were not sure about the answer. Most of the respondent's answered incorrectly maybe because they do not know that this logo is not been use anymore by JAKIM; as this logo was once been used and had been replace by logo 5. For halal logo number 3 and 4, although majority of respondent answered correctly, confusion still exists.

\section{TABLE I: DESCRIPTIVE STATISTICS OF RESPONDENTS}

\begin{tabular}{|c|c|}
\hline & $\%$ \\
\hline \multicolumn{2}{|l|}{ Gender } \\
\hline Male & 38.2 \\
\hline Female & 61.8 \\
\hline \multicolumn{2}{|l|}{ Age } \\
\hline $18-24$ & 42.7 \\
\hline $25-31$ & 20.9 \\
\hline $32-38$ & 18.2 \\
\hline $39-45$ & 6.4 \\
\hline$>45$ & 11.9 \\
\hline Education level & \\
\hline SPM and Below & 5.5 \\
\hline STPM / Diploma & 17.3 \\
\hline Degree / / Master & 73.6 \\
\hline $\mathrm{PhD}$ & 3.6 \\
\hline $\begin{array}{l}\text { Monthly income } \\
<\text { RM 2,000 }\end{array}$ & 45.0 \\
\hline RM 2,000 - RM 3, 000 & 29.1 \\
\hline RM 3, 001 - RM 6, 000 & 15.0 \\
\hline RM 6, 001 - RM 9, 000 & 4.5 \\
\hline RM 9, 001 and above & 6.3 \\
\hline
\end{tabular}

$n=110$

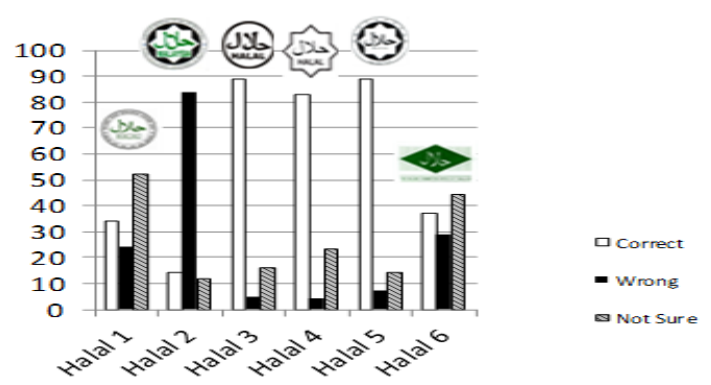

Fig. 2. Knowledge towards the halal logo.

Logo 5 and 6 are the only logos that are approved by JAKIM. Most of the respondents recognized that logo 5 is approved since the percentage of correct answer is high $(80.9 \%)$ compared to $\log$ o 6 which only $33.6 \%$ answered correctly. Only the small scale of respondents (6.4\%) answered incorrectly for logo 5 compared to $26.4 \%$ answered incorrectly for logo 6 . The remaining respondent for both $\log _{0} 5$ and 6 were not sure about the status of the $\log _{0}(12.7 \%$ and $40 \%$ for both logo 5 and 6 respectively).

\section{A. Descriptive Analysis of the Variables}

The results of the reliability test mean and standard deviation for the Independent Variables (Knowledge and Religiosity) and Dependent Variable (Behavior) are summarized and presented in Table II. The Cronbach's Alpha $(\alpha)$ is all above the recommended threshold of 0.50 . This indicates that all variables have an acceptable internal consistency.

Logo 5 and 6 are the only logos that are approved by JAKIM. Most of the respondents are highly recognize that logo 5 is approved since the percentage of correct answer is high $(80.9 \%)$ compared to logo 6 which only $33.6 \%$ have got the right answer. Only the small scale of respondents $(6.4 \%)$ have answer it incorrectly for logo 5 compared to $26.4 \%$ of respondent has answer incorrectly for logo 6 . The remaining respondent for both logo 5 and 6 are not sure about the status of the logo $(12.7 \%$ and $40 \%$ for both $\log 5$ and 6 respectively).

TABLE II: RELIABILITY TEST

\begin{tabular}{lccc}
\hline \multicolumn{1}{c}{ Items } & Mean & $\begin{array}{c}\text { Cronbach's } \\
\text { Alpha }(\boldsymbol{\alpha})\end{array}$ & $\boldsymbol{N}$ of Items \\
\hline Knowledge & 3.28 & 0.809 & 6 \\
Religiosity & 4.13 & 0.816 & 10 \\
& & & \\
Behaviour & & & 7 \\
Food & 4.70 & 0.682 & 7 \\
Cosmetic & 4.14 & 0.875 & \\
& & & 30 \\
Overall & & 0.866 & \\
\hline
\end{tabular}

\section{B. Hypotheses Testing}

The relationship between both independent variables; Knowledge and Religiosity and the dependent variable; Behavior are being tested using multiple regression analysis. Table IV indicates that the $R^{2}$ value is 0.163 ; it means that only $16.3 \%$ of the variance in the dependent variables (behavior) is explained by both independent variables (knowledge and religiosity) and it is significant at the p-value of 0.000. Knowledge however was found not significant in explaining variation in attitudes towards cosmetic product with a $p$-value $>0.05$. However, religiosity was found to be significant in influencing respondent's behavior towards halal cosmetic products since the $p$-value is less than 0.05 . The study accepted $H 2$ but fail to accept $H 1$.

TABLE III: COEFFICIENT REGRESSION

\begin{tabular}{llccc}
\hline $\begin{array}{l}\text { Dependent } \\
\text { Variable }\end{array}$ & $\begin{array}{l}\text { Independent } \\
\text { Variables }\end{array}$ & $\begin{array}{c}\text { Standardized } \\
\text { Coefficient } \\
\text { (Beta) }\end{array}$ & $t$ & Sig. \\
\hline $\begin{array}{l}\text { Behavior on } \\
\text { Cosmetic }\end{array}$ & Knowledge & -0.13 & -1.33 & 0.19 \\
& Religiosity & 0.44 & 4.52 & 0.00 \\
\hline
\end{tabular}


TABLE IV: MODEL SUMMARY AND ANOVA

\begin{tabular}{|c|c|c|c|c|}
\hline & \multicolumn{2}{|c|}{ Model Summary } & \multicolumn{2}{|c|}{ ANOVA } \\
\hline & $\boldsymbol{R}$ & $R^{2}$ & t. & Sig. \\
\hline $\begin{array}{l}\text { Behaviour on } \\
\text { Cosmetic }\end{array}$ & 0.403 & 0.163 & 10.390 & 0.000 \\
\hline
\end{tabular}

The study test the $H 3$, if there is a significant difference between the behavior towards halal food product and halal cosmetic product using the Paired Sample T-Test. Results indicates there is a significant difference between the two products. Respondent's behavior on halal food products is more sensitive compared to halal cosmetic products which could be supported by the mean score of both halal products (4.92 for halal food and 4.36 for halal cosmetic). As such, H3 is supported.

TABLE V: PAIRED SAMPLE T-TEST FOR BEHAVIOUR TOWARDS HALAL PRODUCTS

\begin{tabular}{lccc}
\hline \multicolumn{1}{c}{$\begin{array}{c}\text { Independent } \\
\text { Variable }\end{array}$} & $t$ & df & $\begin{array}{c}\text { Sig. } \\
\text { (2-tailed) }\end{array}$ \\
\hline $\begin{array}{l}\text { Behaviour on Halal food } \\
\text { products Behaviour on } \\
\text { Halal cosmetic products }\end{array}$ & 8.38 & 109 & 0.000 \\
\hline
\end{tabular}

TABLE VI: PAIRED SAMPLE T-TEST FOR BEHAVIOUR TOWARDS HALAL PRODUCTS

\begin{tabular}{lccc}
\hline \multicolumn{1}{c}{$\begin{array}{c}\text { Independent } \\
\text { Variable }\end{array}$} & Mean & $\begin{array}{c}\text { Std. } \\
\text { Deviation }\end{array}$ & $\begin{array}{c}\text { Sig. } \\
\text { (2-tailed) }\end{array}$ \\
\cline { 1 - 2 } $\begin{array}{l}\text { Behaviour on Halal } \\
\text { food products }\end{array}$ & 4.92 & 0.374 & \\
\cline { 1 - 2 } $\begin{array}{l}\text { Behaviour on Halal } \\
\text { cosmetic products }\end{array}$ & 4.36 & 0.000 & \\
\hline
\end{tabular}

\section{CONCLUSION}

This study concludes that religiosity is more influential towards behavior compared to halal knowledge. Thus, marketers must enhance their marketing activities by adopting the element of religiosity to influence halal conscious consumer and in the same time they will create product differentiation. Even though it has been prove that respondent's behavior is more likely towards halal food products compared to halal cosmetic products, emphasising again on what [5], [6] claims that those who use halal are always loyal to halal brands so there is no serious impact of the downturn. Thus, marketers or manufacturers should consider getting the halal certification for their products since it's no serious downturn as halal certification is now considered to be one of the branding strategies for those who can see the opportunities.

This study offers some practical implications. First, as there is a positive relationship between religiosity and attitude, firms should advertise their Halal cosmetic products through a way that shows people who has high level of religiosity use Halal cosmetic products. Second, since the relationship between attitude and intention to choose Halal cosmetics is similar to the relationship for Halal foods, marketers may use similar manners to promote these two Halal products. However, they should be aware of that the consumers' attitude and intention to choose Halal foods is higher than Halal cosmetics.

\section{ACKNOWLEDGMENT}

The authors would like to thanks the Ministry of higher education for funding this research through exploratory research grants scheme.

\section{REFERENCES}

[1] W. C. Swidi, M. G. Hassan, A. A. Hosam, and A. W. M. Kassim, "The mainstream cosmetics industry in Malaysia and the emergence, growth, and prospects of halal cosmetics," in Proc. the Third International Conference on International Studies (ICIS 2010), Hotel Istana Kuala Lumpur, December 1-2, 2010, pp. 1-20.

[2] Opportunity Malaysia: Mission to Malaysia. (2005). [Online]. Available: http://www.malaysiamission.com

[3] A. Lowe. (June 2010). On steady demand drives halal cosmetics industry. Gulf News. [Online]. Available http://gulfnews.com/business/retail/steady-demand-drives-halal-cosm etics-industry-1.641165

[4] Halcos. The new global business wave. (2011). [Online]. Available: http://www.halcos.org

[5] J. Ireland and S. A. Rajabzadeh, "UAE consumer concerns about $<$ IT $>$ halal $</$ IT $>$ products," Journal of Islamic Marketing, vol. 2, iss. 3, pp. 274-280, 2011.

[6] D. K. Yousef. (September 8, 2010). Halal food numbers look tasty. Gulf News. [Online]. Available: http://gulfnews.com/business/general/halal-food-numbers-look-tasty1.679007

[7] C. Hornby and S. Yucel. (November 17, 2009). Halal food going mainstream in Europe: Nestle. Reuters. [Online]. Available: http://reuters.com/article/2009/11/17/idINIndia-44025720091117

[8] MATRADE. (2011). [Online]. Available: http://www.matrade.gov.my/en/foriegn-buyers-section/69-industry-wr ite-upproducts/519-chemicals-a-chemical-products

[9] The Chemical Engineering. (May 2010). A Future in Halal Cosmetics. [Online]. Available: www.tcetoday.com

[10] A. Mukhtar and M. M. Butt, "Intention to choose $<$ IT $>$ Halal $</$ IT $>$ products: the role of religiosity," Journal of Islamic Marketing, vol. 3 Iss: 2, pp. 108-120, 2012

[11] H. A. Rahman, W. I. W. Ahmad, M. Y. Mohamad, and Z. Ismail, "Knowledge on Halal food amongst food industry entrepreneurs in Malaysia," Asian Social Science, vol. 7, no. 12, pp. 216, 2011

[12] J. Aertsens, K. Mondelaers, W. Verbeke, J. Buysse, and G. V. Huylenbroeck, "The influence of subjective and objective knowledge on attitude, motivations and consumption of organic food," British Food Journal, vol. 113, Iss. 11, pp. 1353-1378, 2011.

[13] G. Chryssochoidis, "Repercussions of consumer confusion for late introduced differentiated products," European Journal of Marketing vol. 34 , iss. $5 / 6$, pp. 705-722, 2000 .

[14] S. Padel and C. Foster, "Exploring the gap between attitudes and behavior: Understanding why consumers buy or do not buy organic food," British Food Journal, vol. 107, iss. 8, pp. 606-625, 2005.

[15] S. B. Ankomah and E. K. Yiridoe. (2006). Organic and conventional food: A literature review of the economics of consumer perceptions and preferences. Final Report. [Online]. Available: http://www.organicagcentre.ca/Docs/BONTI\%20\&\%20YIRIDOE\%2 0April\%2028\%202006\%20Final.pdf

[16] A. A. Gracia and T. de Magistris, "Organic food product purchase behavior: a pilot study for urban consumers in the South of Italy," Spanish Journal of Agricultural Research, vol. 5, no. 4, pp. 439-45, 2007.

[17] D. J. Stobbelaar, G. Casimir, J. Borghuis, I. Marks, L. Meijer, and S Zebeda, "Adolescents' attitude towards organic food: A survey of 15to 16-year old school children," International Journal of Consumer Studies, vol. 31, Iss. 4, pp. 349-356, 2007.

[18] B. J. Johnson, "Does adolescent religious commitment matter? A re-examination of the effects of religiosity on delinquency," Journal of Research in Crime and Delinquency, vol. 38, no. 1, pp. 22-43, 2001.

[19] E. D. Run, M. Butt, K. Fam, and T. Jong, "Attitudes towards offensive advertising: Malaysian Muslims' view," Journal of Islamic Marketing, vol. 1 , no. 1 , pp. $25-36,2010$

[20] B. O'Connell, "Dimensions of religiosity among Catholics," Review of Religious Research, vol. 16, no. 3, pp. 198-207, 1978. 
[21] S. S. Alam, R. Mohd, and B. Hisham, "Is religiosity an important determinant on Muslim consumer behavior in Malaysia?" Journal of Islamic Marketing, vol. 2, iss. 1, pp. 83-96, 2011.

[22] E. C. Hirschman, "Religious affiliation and consumption processes," Research in Marketing, vol. 6, pp. 131-170, 1983.

[23] N. Delener, "Religious Contrasts in Consumer Decision Behavior Patterns: Their Dimensions and Marketing Implications," European Journal of Marketing, vol. 28, iss. 5, pp. 36-53, 1994.

[24] C. Pettinger, M. Holdsworth, and M. Gerber, "Psycho-social influences on food choice in Southern France and Central England," Appetite, vol. 42, no. 3, pp. 307-316, 2004.

[25] K. Mullen, R. Williams, and K. Hunt, "Irish descent, religion and food consumption in the west of Scotland," Appetite, vol. 34, pp. 47-54, 2000.

[26] G. Rezai, M. Zainalabidin, S. M. Nasir, and F. E. Chiew, "Non-Muslims awareness of Halal principles and related food products in Malaysia," International Food Research Journal, vol. 17, pp. $667-674,2010$

[27] F. Salman and K. Siddiqui, "An exploratory study for measuring consumers awareness and perceptions towards halal food in Pakistan," Interdisciplinary Journal of Contemporary Research in Business, vol. 3 no. 2, pp. 639, 2011.

[28] S. Lada, G. H. Tanakinjal, and H. Amin, "Predicting intention to choose $<$ IT $>$ halal $</$ IT $>$ products using theory of reasoned action," International Journal of Islamic and Middle Eastern Finance and Management, vol. 2, iss. 1, pp. 66-76, 2009.

[29] A. Aziz, M. Amin, and Z. Isa. "The perception to choose halal cosmetics products: An empirical study for Malaysian consumers," presented at the 6th International Conference on Business, Management and Economics (ICBME'10), Turkey, October 7-9, 2010.

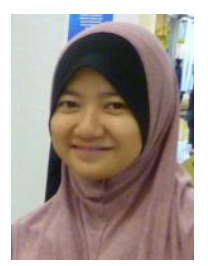

Ahlam Nuwairah Ahmad is a student at Faculty of Economics and Management, Universiti Putra Malaysia. She majors are in International Business and has deep interest in research relating to International Business with a specific focus on the internationalization of Halal products.

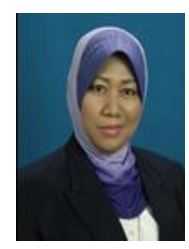

Azmawani Abd Rahman is an associate professor and Deputy Dean for Research and Graduate Studies at Faculty of Economics and Management, Universiti Putra Malaysia (UPM). She holds a bachelor of Science in Finance from the University of South Alabama, United States and $\mathrm{PhD}$ in Operations and Technology Management from the Aston University, United Kingdom. Currently she is an associate researcher at Halal Product Research Institute, UPM. She has published research papers in refereed journals which include Transaction on Engineering Management (IEEE), Journal of Manufacturing Technology Management, and International Journal of Production Research. Her research interests are in the areas of advanced manufacturing technology management, Manufacturing supply chain management, Halal product and Tourism supply chain management, and Organizational culture

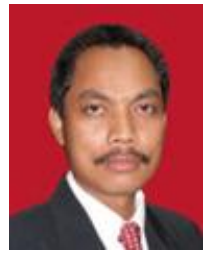

Suhaimi Ab Rahman is a senior lecturer at Faculty of Econmics and Management and an affiliate member of Halal Institute, Universiti Putra Malaysia. $\mathrm{He}$ completed his PhD in Law at the University of Wales, Aberystwyth. His research focused on the right of guarantor in a secured transaction. His current research interests include the halal product laws, policy and management. 